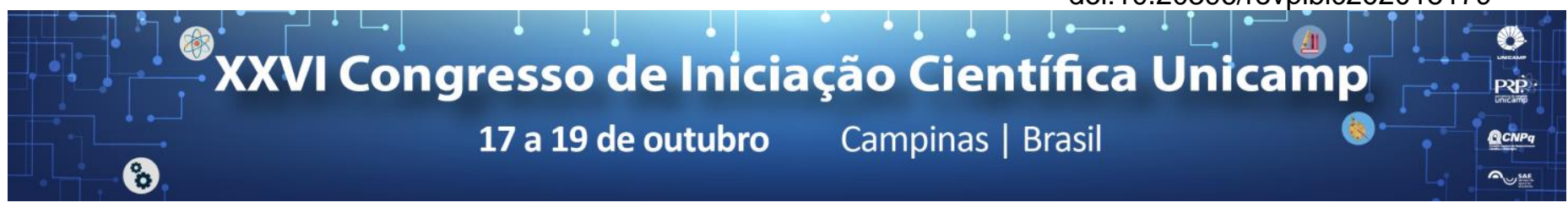

\title{
Estudo da biodegradação do fipronil no solo mediante a adição de aditivo biológico
}

\section{Bárbara Acorsi; Cassiana Maria Reganhan Coneglian}

\section{Resumo}

O fipronil é um inseticida utilizado no controle de insetos em plantações de cana-de-açúcar, soja, milho, algodão, batata e no controle de pulgas, carrapatos e piolhos em animais domésticos. A aplicação dessas moléculas químicas se mostra eficiente no controle dos insetos alvo, porém seu manuseio sem controle pode afetar organismos não alvo. A literatura tem mostrado que o fipronil pode provocar grandes prejuízos ao ambiente, principalmente a biota. Neste trabalho avaliou-se a biodegradação do pesticida fipronil no solo com a adição de aditivo biológico.

Palavras-chave: Fipronil, biodegradação, respirometria.

\section{INTRODUCÃ̃O}

A avaliação ambiental de um agrotóxico é importante para ajudar na minimização de possíveis riscos ambientais. Para avaliar a biodegradação de compostos orgânicos no solo, a respiração da microbiota tem sido utilizada como importante ferramenta, a partir de medidas da evolução de $\mathrm{CO}_{2}$ e/ou absorção de $\mathrm{O}_{2}$. Pode-se empregar a técnica de respirometria, utilizando-se respirômetro de Bartha e Pramer. A degradação do fipronil forma fipronil sulfona, sulfeto de fipronil (oxidação biótica e abiótica) e fipronil desulfinil (fotólise), entretanto biodegradação é a via mais significativa.

O objetivo deste trabalho foi avaliar a biodegradabilidade do fipronil em solos rico em matéria orgânica e outro com características de cerrado, acrescido do aditivo biológico denominado Microgeo, mediante o método de respirometria de Bartha e Pramer.

\section{RESULTADOS E DISCUSSÃO}

As figuras 1 e 2 expressam os resultados da geração acumulada de $\mathrm{CO}_{2}(\mathrm{mg} / \mathrm{L})$ da biodegradação do fipronil em latossolo e em solo arenoso, ambos acrescidos com 0 aditivo biológico. A respirometria foi avaliada durante o período de 64 dias (Figura 1) e 30 dias (Figura 2) em estufa BOD a $28 \pm 2^{\circ} \mathrm{C}$, de acordo com OECD (2002).

Figura 1. Geração acumulada de $\mathrm{CO}_{2}(\mathrm{mg} / \mathrm{L})$, em ensaio de biodegradação do fipronil em latossolo, acrescidos de aditivo biológico, durante a período de 64 dias a $28 \pm 2^{\circ} \mathrm{C}$.

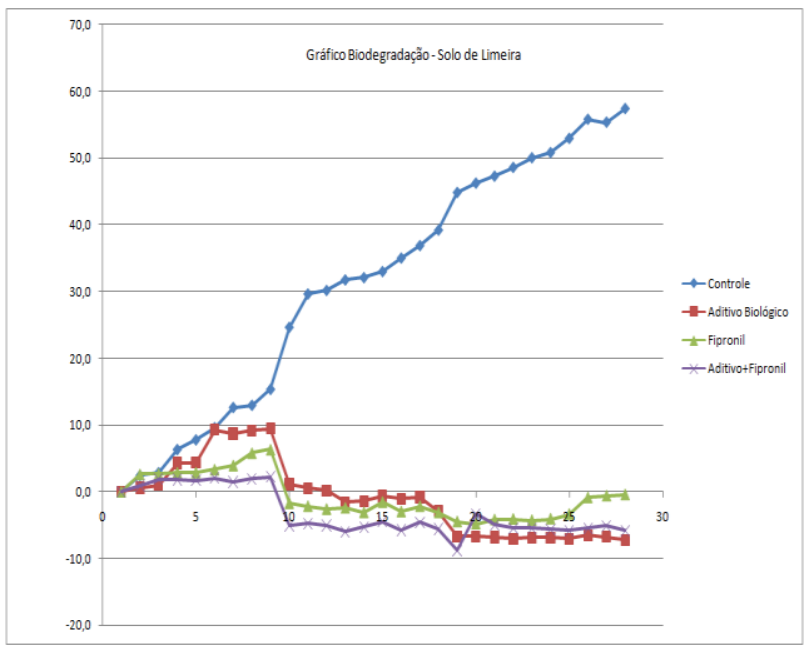

Figura 2. Geração acumulada de $\mathrm{CO}_{2}(\mathrm{mg} / \mathrm{L})$, em ensaio de biodegradação do fipronil em solo arenoso, acrescidos de aditivo biológico, durante a período de 30 dias a $28 \pm 2^{\circ} \mathrm{C}$.

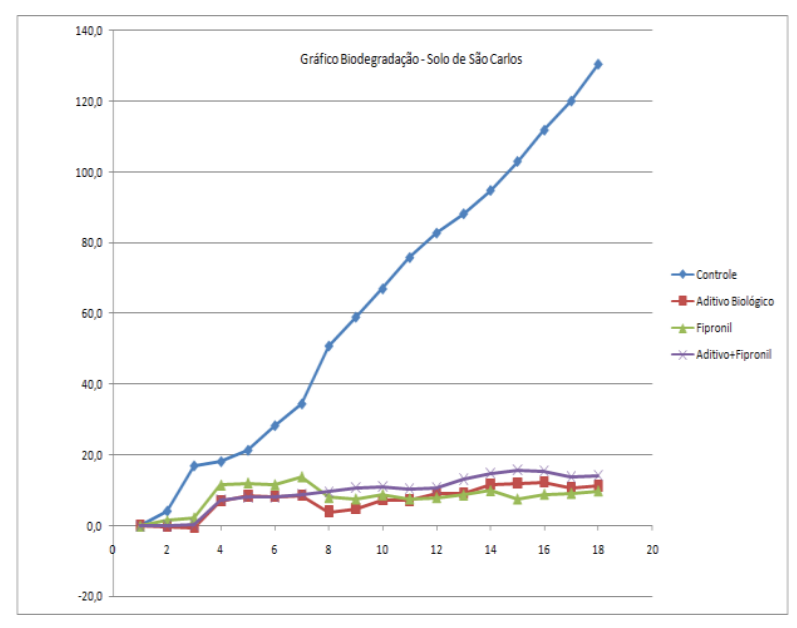

\section{CONCLUSÕES}

Considerando os resultados obtidos, conclui-se que a adição do aditivo biológico no ensaio de biodegradação em ambos os solos, não apresentaram resultado significativo na biodegradação do inseticida fipronil.

Os resultados estão de acordo com a literatura, onde o fipronil degrada-se lentamente, em solo argiloarenoso a vida média do fipronil é de 122-128 dias e se aplicado em outros tipos de solo pode variar de 3-7 meses, evidenciando que o composto amplamente utilizado em diversas culturas apresenta lenta biodegradação no ambiente.

\section{AGRADECIMENTOS}

A Pró-reitoria de Pesquisa da Unicamp, ao CNPq, à orientadora Cassiana Maria Reganhan Coneglian e ao Técnico Gilberto de Almeida.

CAPPELINI, L.T.D. et al. (2018). Burkholderia thailandensis: the Main Bacteria Biodegrading Fipronil in Fertilized Soil with Assessment by a QuEChERS/GC-MS Method. J. Braz. Chem. Soc., Vol. 00, No. 00, 1-10.

OECD Guidelines for the Testing of Chemicals. Test $n^{\circ}$ 307: Aerobic and Anaerobic transformation in soil, Organization for the Economic Cooperation and Development, 2002.

USEPA, 1996. New pesticide fact sheet. PB96 - 181516. EPA 737 - F -96 005. U.S. EPA Office of Prevention, Pesticides and Toxic Substances. 